\title{
Disclosure of conflicts of interest and credibility for the medical profession
}

This article was published in the following Dove Press journal:

Substance Abuse and Rehabilitation

30 December 2015

Number of times this article has been viewed

\author{
Alain Braillon ${ }^{1, *}$ \\ Bernard Granger ${ }^{2, *}$ \\ 'Alcohol Treatment Unit, Amiens \\ University Hospital, Amiens, \\ ${ }^{2}$ Department of Psychiatry, Tarnier \\ Hospital (AP-HP), Paris, France \\ *Both authors contributed equally to \\ this work
}

\section{Dear editor}

We were surprised by an unbalanced review about nalmefene for alcohol dependence, wherein the authors had stated no conflicts of interest (COIs). ${ }^{1}$ The Editor in Chief and the Publisher were very professional when we stressed our concerns, and they must be commended. They accepted publication of a critical free evaluation based upon evidence where we also called for full disclosure of COIs. ${ }^{2}$

The authors' correction acknowledged several links (consultancies, honoraria, speaker fees, travel grants) for several pharmaceutical companies, including Lundbeck, which markets nalmefene. ${ }^{3}$ However, existing links with Grey Healthcare France were not provided. Grey Healthcare is "a full-service, global, integrated communications agency", which claims "our market-leading campaigns generate brand engagement, grow sales ...", and has among its clients Lundbeck for nalmefene. Such links should have been disclosed according to the French Sunshine Act.

Whatever the law could be, science integrity requires that all COIs, financial or otherwise, that could ever have affected a researcher's judgment should be declared. They overcome our most basic medical commitment: to care for those who need it, and also constitute a crisis of credibility for the medical profession. ${ }^{4}$

\section{Disclosure}

$\mathrm{AB}$ was coinvestigator for the clinical trial ALPADIR (baclofen). BG has no conflict of interest related to this communication.

\section{References}

1. Paille F, Martini H. Nalmefene: a new approach to the treatment of alcohol dependence. Subst Abuse Rehabil. 2014;5:87-94.

2. Braillon A, Granger B. Nalmefene and alcohol dependence: a new approach or the same old unacceptable marketing? Subst Abuse Rehabil. 2015;6:75-80.

Correspondence: Alain Braillon

Alcohol Treatment Unit,

Amiens University Hospital,

Amiens 80000, France

Email braillon.alain@gmail.com
3. Paille F, Martini H. Nalmefene: a new approach to the treatment of alcohol dependence [corrigendum]. Subst Abuse Rehabil. 2015;6:81-82.

4. Braillon A. Conflicts of interest and the future of medicine: the United States, France and Japan. J Public Health Policy. 2011;32:391-398. 
Dove Medical Press encourages responsible, free and frank academic debate. The content of the Substance Abuse and Rehabilitation 'letters to the editor' section does not necessarily represent the views of Dove Medical Press, its officers, agents, employees, related entities or the Substance Abuse and Rehabilitation editors. While all reasonable steps have been taken to confirm the content of each letter, Dove Medical Press accepts no liability in respect of the content of any letter, nor is it responsible for the content and accuracy of any letter to the editor.

Substance Abuse and Rehabilitation

Dovepress

\section{Publish your work in this journal}

Substance Abuse and Rehabilitation is an international, peer-reviewed, open access journal publishing original research, case reports, editorials, reviews and commentaries on all areas of addiction and substance abuse and options for treatment and rehabilitation. The manuscript management system is completely online and includes a very quick and fair peer-review system. Visit http://www.dovepress.com/testimonials.php to read real quotes from published authors.

Submit your manuscript here: http://www.dovepress.com/substance abuse-and-rehabilitation-journal 